\title{
Propolis Diterpenes as a Remarkable Bio-Source for Drug Discovery Development: A Review
}

\author{
Noushin Aminimoghadamfarouj and Alireza Nematollahi * \\ Faculty of Pharmacy A15, The University of Sydney, Sydney NSW 2006, Australia; nami1357@uni.sydney.edu.au \\ * Correspondence: anem7250@uni.sydney.edu.au; Tel.: +61-2-9351-6528; Fax: +61-2-9351-4391
}

Received: 26 May 2017; Accepted: 15 June 2017; Published: 17 June 2017

\begin{abstract}
Propolis is one of the complex, but valuable, bio-sources for discovering therapeutic compounds. Diterpenes are organic compounds composed of four isoprene units and are known for their biological and pharmacological characteristics, such as antibacterial, anticancer, and anti-inflammatory activities. Recently, advancements have been made in the development of antibacterial and anticancer leads from propolis-isolated diterpenes, and scrutiny of these compounds is being pursued. Thus, this review covers the progress in this arena, with a focus on the chemistry and biological activities of propolis diterpenes. It is anticipated that important information, in a comprehensive and concise manner, will be delivered here for better understanding of natural product drug discovery research.
\end{abstract}

Keywords: propolis; diterpenes; anticancer; antibacterial; Brazilian propolis; Mediterranean propolis; European propolis

\section{Introduction}

Honey bees have been known to humans for more than 15,000 years, and archaeological studies have revealed rock paintings describing bees and hive beekeeping, and how human beings domesticated wild bees and obtained benefits from them, using beekeeping apparatus [1,2]. There is evidence regarding the frequent usage of the term "bee king" by ancient Egyptian kings [3]. Ancient physicians and priests exploited from bees products to protect their gods and holy places, cure patients, and especially honey for themselves to remain in good health [4]; also, there are materials in holy books about the benefits and positive aspects of using honey and bees for the human body [5]. Moreover other honey bee hive products, such as propolis and royal-jelly, have been extensively used in traditional remedies all around the world since early human history [6].

Propolis (bee glue), the resinous material that can be seen in different colors, is mostly collected by honey bees (Apis mellifera L., belonging to the family of Apidae, have been studied extensively for their behavior, morphology, and physiology [7]) from bark cracks and leaf buds of various types of plants. Bees carry propolis to the bee hive where they use this dark adhesive substance to seal the walls of their hive to fortify the skeletons and structures of combs, and also to mummify successful intruders' cadavers which bees have killed inside but cannot convey out of their hive to prevent their decomposition [8,9]. Propolis enables bees to protect their colony against hive invaders by minimizing the hive entrance size. Additionally, bees can preserve their society against several diseases, such as molds and bacterial infections, through the antimicrobial and antifungal properties of propolis [8]. In linguistics the term propolis originates from the Greek pro (for "in front of", "at the entrance to") and polis ("city" or "community") [10].

Meyer has described how the bees' leg movement is actively involved in the propolis collection procedure, along with assistance from the bees' mouth parts, tongue, mandibles, and corbiculae. Once pollen baskets on the bee hind legs get full, bees will fly back to hive where propolis removal is carried 
out by mainly older bees, whose wax glands have been almost atrophied, while younger bees are busy building combs and capping cells for honey [11]. Three main theories have been discussed to highlight the factors affecting propolis collection by bees; firstly, the availability of propolis in the hive; secondly, the climate and seasonal changes; and, thirdly, some innate changes happening in the propolis foragers' performance by late summer [12]. Some breeds of bees collect propolis more than others; for example, the grey mountain Caucasian honey bees have the highest activity in propolis collection [13], whereas some species and varieties of honey bees show very little interest in propolis and almost make no use of it, such as tropical honeybees (Apis cerana, Apis florae, and Apis dorsata) and African Apis mellifera [14].

Propolis melting point is known to be around $65^{\circ} \mathrm{C}$, but in some samples it goes higher, up to $100{ }^{\circ} \mathrm{C}$ [15]. About half of the propolis is composed of resinous materials, and other main constituents are as follows: wax, essential oils, and pollen [16]. The chemical groups of compounds identified in the propolis sample include flavonoids, aliphatic acids and esters, aromatic acids and esters, chalcones, terpenes, lignans, stilbenes, prenylated stilbenes, prenylated benzophenones, benzofuran, and sugars [16-18]. In recent years, there have been several studies done on single isolated compounds from propolis $[18,19]$. The chemical composition of the propolis varies based on its botanical origin. Propolis collected from different botanical regions exhibits different chemical outlines. There is no information showing that bees can engage any chemical process on the collected resins [20].

Propolis has a strong background use in human history, and around 400 years ago it was formally accepted as a medication by pharmacopoeias [21]; however, it was not until the last century that propolis popularity soared in European societies owing to its antibacterial characteristics. In modern times, propolis has been recommended by herbal specialists to manage and overcome infections, dermatitis, and gastroduodenal ulcers. In recent decades propolis is known as a popular complementary medicine in various dosage forms, such as lozenges, creams, and mouthwashes. Moreover, it enters into the cosmetic industries as a unique natural constituent [10].

Diterpene, a type of terpene, is one of the outstanding chemical structures inside propolis and has shown a broad array of biological effects, such as antibacterial, antioxidant, anti-inflammatory, antifungal, antiplatelet, anticancer, and antihypertensive activities [22-33]. Diterpene forms the primary skeleton chemical structure of many biologically-important natural compounds. Likewise, regarding the drug discovery rules, by assistance of medicinal chemistry, structure activity relationships, and semi-synthesis techniques, these isolated compounds have a sufficient potential to be used in drug development [34-38].

Herein, before focusing on the properties of diterpenes isolated from propolis, a concise summary of propolis pharmacological and biological activities is presented and then, in this review, we discuss the biological and pharmacological activity of the diterpenoid propolis along with their chemical structures, sources, and their probable action mechanisms, to display the potency of such naturally-occurring organic molecules as novel resources for future drug discovery.

\section{Propolis Biological Activity}

\subsection{Antibacterial, Antiviral, Antifungal, and Antiparasite Activities}

The very first data published regarding the antibacterial activity of propolis extract dates back to 1980, showing that sensitivity of Streptococcus species to propolis extract was reported [39]. Later, the alcoholic extract of propolis effectiveness was remarked against a Bacillus strain [40] and growth inhibition activity (at $3 \mathrm{mg} / \mathrm{mL}$ ) was recorded against Pseudomonas aeruginosa and Escherichia coli, even though no activity was observed for propolis extract on Klebsiella pneumoniae [16,41,42]. Antibacterial synergistic effect was seen by alcoholic extract against Staphylococcus aureus and Escherichia coli when tested simultaneously in the medium with other antibiotics $[43,44]$.

Formation of Flu viruses (A and B types) are affected by propolis [45]. Herpes virus counts were dramatically reduced by using propolis $(30 \mu \mathrm{g} / \mathrm{mL})$; however, less inhibition was seen against 
adenoviruses [46]. The observed antiviral activity for propolis originates from its complicated chemical compositions [47-51], and it was also reported that propolis can affect the cell receptors at the viral adsorption step [52].

Propolis antifungal activity was tested on Trichophyton and Mycrosporum species, along with propylene glycol solution, and exhibited synergistically-increased antifungal activity [53]. The same result was obtained using propolis along with other antifungal drugs on Candida albicans [54-56]. According to Fernandes Junior et al., propolis extract was examined on several fungi strains (Candida species) and based on the results more than $95 \%$ of tested strains were sensitive to propolis ethanol extract in concentrations less than 5\% [16]. Propolis is reported to inhibit the growth of Trichophyton verrucosum at concentrations of 5\% and 10\% [57]. Antifungal activity of propolis ethanolic extract and its four different fractions against Penicillium italicum were assessed and obtained results showed all tested samples having strong antifungal properties, especially the ethyl acetate fraction [58].

Ghanaian propolis was evaluated for antiparasitic effects on Trypanosoma brucei, which causes the human sleeping sickness predominately in sub-Saharan Africa [59]. Propolis has showed complete inhibitory effects on the Fasciola gigantica eggs (at $200 \mu \mathrm{g} / \mathrm{mL}$ ) [60]. According to Higashi et al., propolis strongly inhibits proliferation of Trypanosoma cruzi at $15 \mu \mathrm{g} / \mathrm{mL}$ [61]. In 1988, propolis was promisingly proposed to manage giardiasis (causing diarrhoea) as a natural source with the benefit of showing a minimum level of side effects during treatment [62]. The alcoholic extract propolis can terminate the proliferation of protozoa, such as Toxoplasma gondii and Trichomonas vagilanis. The extract at the concentration of $150 \mathrm{mg} / \mathrm{mL}$ showed lethal effects on three strains of Trichomonas vaginalis [63]. Propolis showed coccidiostat activity on Chilomonas paramecium [16]. Propolis ethanolic extract could strongly inhibit the growth of Giardia lamblia during the in vitro assay at the concentration of $11.6 \mu \mathrm{g} / \mathrm{mL}$ [64]. Antifungal and anthelmintic activities have been reported from Argentinian propolis ethanolic extract samples [65]. Likewise, for the antifungal activity from diterpenoid propolis, there is a mixture which decreased the adhesion of fungi to surface and has been used as a dental medicine [66].

\subsection{Anti-Inflammatory Effect}

Chinese and Brazilian propolis samples were studied for their anti-inflammatory mechanism of action. Both samples could affect and alter lipoglycan- and endotoxin-based inflammatory cascade in rodent macrophages. The in vitro experiment results confirmed that propolis extract decreases nuclear factor- $\mathrm{kB}(\mathrm{NF}-\mathrm{kB})$ stimulation and suppresses the synthesis process of ubiquitin units. To conclude, although the alcoholic extract from China has dramatic differences compared to the Brazilian extract, both samples showed anti-inflammatory properties by blocking NF- $\kappa B$ function [67]. Argentinian propolis ethanolic extracts showed in vitro anti-inflammatory activity by reducing lipoxygenase and cyclooxygenase activities and nitric oxide production (by decreasing inducible nitric oxide synthase protein expression) [65]. Brazilian red propolis was analysed and anti-inflammatory and antinociceptive activities were observed through in vivo models [68]. Propolis samples collected from Chile were analysed for their phenolic profile and anti-inflammatory activity. The samples exhibited anti-inflammatory activity through inhibitory effects on nitric oxide release [69]. Nepalese propolis suppressed the interleukin-33-induced messenger RNA expression genes and established its anti-inflammatory effects in such a mechanism of action [70].

\subsection{Cytotoxic Effect}

According to Haldon et al., in 1980, fractions of propolis exhibited cytotoxic properties (at 2.6-3.3 $\mu \mathrm{g} / \mathrm{mL}$ ) on HeLa (human cervical carcinoma) and on human KB (nasopharynx carcinoma) cell lines. This result was confirmed by Ban et al., in 1983 [16]. The red propolis from Brazil has been reported by Awale et al. to possess cytotoxic activities [71]. Greek propolis showed anti-proliferative activity against human colon adenocarcinoma cells (HT-29) [72]. Brazilian propolis samples have cytotoxic activities against human hepatocellular carcinoma cell lines [73], and also the in vivo assay cytotoxic effects were recorded on mouse skin tumours [74]. 


\subsection{Immunomodulatory Action}

There is a study about propolis constituents which suppress T-lymphocyte cells but, conversely, can make macrophage function active. The same effect has been claimed for Brazilian propolis [75].

Propolis can affect intrinsic immunity through activating the immune response by increasing the production of cytokines, and elevating the level of expression of Toll-like receptors in spleen cells and macrophages [76]. Some propolis constituents can stimulate chemotactic activity in neutrophil cells. These propolis substances improve neutrophil migration function, which increases the ability of intra-cellular phagocytosis of white blood cells. A partially-purified propolis extract from Argentina showed significant chemotaxis elevation effects on the human immune system [77].

\subsection{Toxicity}

The lethal dose $\left(\mathrm{LD}_{50}\right)$ of propolis has been reported to be around $2000 \mathrm{mg} / \mathrm{kg}$ [78]. Later, it was reported that the $\mathrm{LD}_{50}$ was about $700 \mathrm{mg} / \mathrm{kg}$ for alcoholic propolis extract, while it is reported as $350 \mathrm{mg} / \mathrm{kg}$ for the ether solution of propolis by Russian researchers [12]. The carcinogenesis of propolis in rats by adding propolis at the dose of $1 \mathrm{mg} / \mathrm{mL}$ in rat's drinking water was studied and no differences were observed in controls and treated animals [79]. Propolis dermatitis was first reported from apiarists (assumed as an occupational eczema), later as the usage of propolis developed other non-occupational incidences have also been added to the propolis usage cautions [80]. It was showed that different propolis types can produce different degrees of contact allergy. Propolis allergy has been considered to have high levels of sensitization among children $[81,82]$. In a comprehensive experiment on propolis, patch warnings were recommended in use of the propolis for dermatological purposes for young children [83].

\section{Diterpenes from the Propolis}

Diterpenes belong to the class of terpenes based on having the $C_{20}$ skeleton, composed of four isoprene units originated from mevalonate or deoxy-xylulose phosphate (non-mevalonate) [84]. More than 3000 diterpenes have been explored from nature but only a small number of them have been recognized as clinically effective $[85,86]$. One of the rich resources of pharmacologically-active diterpenes in nature is propolis and these compounds sequestered from propolis might be used directly in treatment per their less toxic effects [87-92]. In this section, the propolis samples are composed of a high amount of diterpenoids (Figure 1), and their chemistry, biological, and pharmacological properties are discussed.

Tri- and di-terpenoids have recently been reported as the major constituents from an analytical study done on a propolis type collected from the southern part of Saudi Arabia. The majority chemical compositions of diterpenes of the propolis ethyl acetate (EA) fraction were compounds 1-5. MTT cell viability assay exhibits that EA fraction have cytotoxic activity against Jurkat T-cells, A549 lung carcinoma, HepG2 liver cancerous, and SW756 cervix carcinoma cell lines with $\mathrm{IC}_{50 \mathrm{~s}}$ in the range $1.8-6.3 \mu \mathrm{g} / \mathrm{mL}$. Exploiting fluorescence microscope techniques, tubulins are recognized as the target for apoptotic properties of the propolis EA fraction, with high percentage content of terpenoids [93].

In a study on nanoparticle drug delivery system of Moroccan propolis, which endorses isocupressic acid (6), the diterpenoid, in high concentrations, having an antibacterial effect against methicillin-resistant Staphylococcus aureus (MRSA), was evaluated [94]. The result was consistent with the collected propolis from the northern part of Morocco (Bhalil) which followed the same proportional constituent pattern (diterpenoids have the highest share of its composition). The Bhalil sample exhibited inhibitory activities against amylase isozymes along with having substantial antioxidant activities [95].

A rare clerodanoid diterpene (7), accompanied by other established diterpenoids were characterized from Brazilian brown propolis, and it showed significant anticancer activities against a 
number of cell lines [96]. Compound 7 was initially reported from the same team as a patent possessing promising cytotoxic effects against LNCap cells to overcome prostate cancer with an $\mathrm{IC}_{50}$ of $6.2 \mu \mathrm{M}$ [97].<smiles>[R3]C1C[C@H]2C(C)(C)C([R])C([R])C[C@]2(C)c2cc(O)c(C(C)C)cc21</smiles>

(1) Ferruginol $\mathrm{R}_{1}:-H, \mathrm{R}_{2}:-H, \mathrm{R}_{3}:-\mathrm{H}$

(2) Sugiol $\quad R_{1}:-H, R_{2}:-H, R_{3}:=O$

(4) Hinokione $R_{1}:=O, R_{2}:-H, R_{3}:-H$

(5) Hinokiol $\quad \mathrm{R}_{1}$ : $-\mathrm{OH}, \mathrm{R}_{2}:-\mathrm{H}_{1} \mathrm{R}_{3}:-\mathrm{H}$

(30) 2-Hydroxyferruginol $\mathrm{R}_{1}:-\mathrm{H}, \mathrm{R}_{2}:-\mathrm{OH}, \mathrm{R}_{3}:-\mathrm{H}$

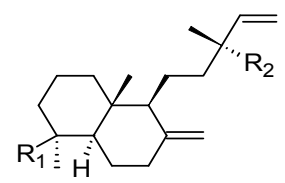

(11) 13-epi-torulosal $\mathrm{R}_{1}:-\mathrm{CHO}, \mathrm{R}_{2}:-\mathrm{OH}$

(12) 13-epi-cupressic acid $\mathrm{R}_{1}:-\mathrm{COOH}, \mathrm{R}_{2}:-\mathrm{OH}$

(13) Acetyl-13-epi-cupressic acid $\mathrm{R}_{1}$ :- $\mathrm{COOH}, \mathrm{R}_{2}$ : -OAc

(19) 13-epi-torulosol $\mathrm{R}_{1}$ : $-\mathrm{OH}, \mathrm{R}_{2}:-\mathrm{CH}_{3}$<smiles>[R]C1[C@H](O)[C@@H](C)O[C@H](OCCC(C)CC[C@H]2C(=C)CC[C@H]3C(C)(C)CCC[C@@]23C)[C@@H]1O</smiles>

(38) Mimosaside A

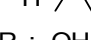

$\mathrm{R}_{1}:-\mathrm{OH}$

(39) Mannopyranoside $R_{1}$ : -OAc

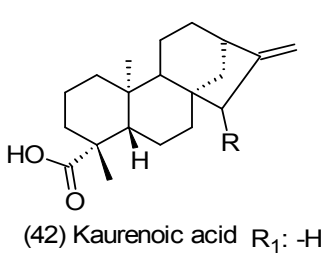

(42) Kaurenoic acid $\mathrm{R}_{1}:-\mathrm{H}$

(43) $\mathrm{R}_{1}:-\mathrm{OCOCH}_{2} \mathrm{CH}\left(\mathrm{CH}_{3}\right)_{2}$ (44) $\mathrm{R}_{1}:-\mathrm{OH}$

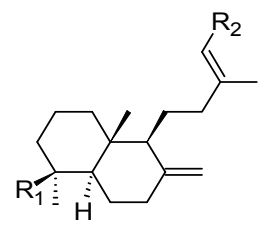

(35/36) 15-oxolabda-8

(40) Agathic acid

(41) Agathic acid-15-methyl ester

(20) Agathodiol $\mathrm{R}_{1}$ : $-\mathrm{CH}_{2} \mathrm{OH}, \mathrm{R}_{2}:-\mathrm{CH}_{2} \mathrm{OH}$

(21) Copalol $\quad \mathrm{R}_{1}$ : $-\mathrm{CH}_{3}, \mathrm{R}_{2}:-\mathrm{CH}_{2} \mathrm{OH}$

(22) isoagatholal $\mathrm{R}_{1}$ : $-\mathrm{CHO}, \mathrm{R}_{2}$ : $-\mathrm{CH}_{2} \mathrm{OH}$

(33) $\mathrm{R}_{1}:-\mathrm{CH}_{3}, \mathrm{R}_{2}:-\mathrm{OCO}\left(\mathrm{CH}_{2}\right)_{7} \mathrm{CH}=\mathrm{CH}-\left(\mathrm{CH}_{2}\right)_{7} \mathrm{CH}_{3}$

(34) $\mathrm{R}_{1}:-\mathrm{CH}_{3}, \mathrm{R}_{2}:-\mathrm{OCO}\left(\mathrm{CH}_{2}\right)_{14} \mathrm{CH}_{3}$

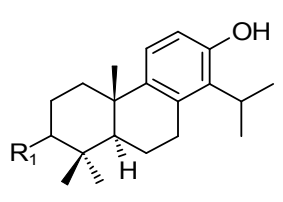

(3) Totarol $\mathrm{R}_{1}:-\mathrm{H}$

(23) Totarolone $R_{1}:=O$
$\mathrm{R}_{1}$ : - $\mathrm{COOH}, \mathrm{R}_{2}:-\mathrm{CHO}$

$\mathrm{R}_{1}$ : - $\mathrm{COOH}, \mathrm{R}_{2}$ : - $\mathrm{COOH}$

$\mathrm{R}_{1}$ : - $\mathrm{COOH}, \mathrm{R}_{2}$ : -COOMe

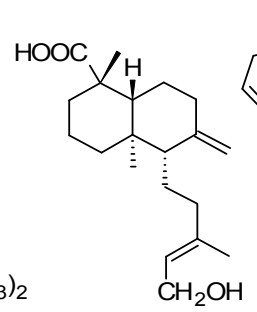

(6) isocupressic acid<smiles>[R7]c1cc2c(cc1C(C)C)CC[C@H]1[C@@](C)(C(=O)O)CCC[C@@]21C</smiles>

(27) 12-Hydroxydehydroabietic acid $\mathrm{R}_{1}:-\mathrm{OH}$ (28) Dehydroabietic acid $\mathrm{R}_{1}:-\mathrm{H}$<smiles>C=C[C@]1(C)C=C2CC[C@H]3[C@](C)(C(=O)O)CCC[C@]3(C)[C@H]2CC1</smiles>

(9) Pimaric acid<smiles>C=CC(C)=CCC1C(=C)CCC2C(C)CCCC12</smiles>

(10) Communic acid<smiles>C=C1CCC2[C@@H](CCCC2(C)C(=O)O)CC1CC[C@H](C)CC=O</smiles>

(16) Imbricataloic acid

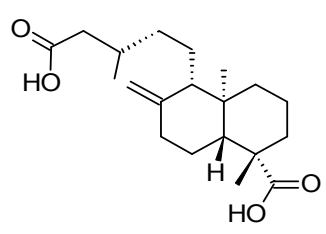

(24) Junicedric acid

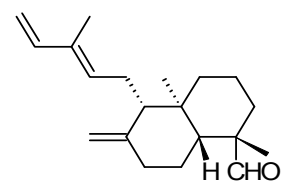

(25) trans-communal<smiles>CC(C)C1=CC2=CC[C@H]3C(C)(C(=O)O)CCCC3(C)C2CC1</smiles>

(26) Abietic acid

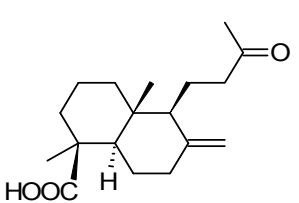

(29)<smiles>CC(C)c1cc2c(cc1O)CCC1C(C)CCCC21C</smiles>

(31) Sempenirol<smiles>C=C[C@]1(O)CC[C@H]2CCCC(C)[C@@H]2CCC1=C</smiles>

(32) Manool

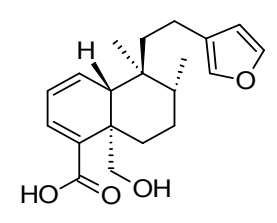

(37)<smiles>CC1=CCC[C@H]2C(CC/C(C)=C/C=O)[C@H](C(=O)O)CCC12C</smiles>

(45)

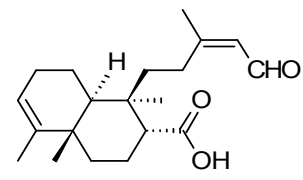

(46)

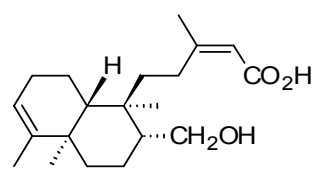

(47) PMS-1

Figure 1. Structures of the isolated bioactive diterpenes from propolis as a natural source.

Propolis samples from the central part of Chile were profiled and the extracts were biologically evaluated against Gram-negative strains, and antibacterial activities were observed. The existence 
of diphenylheptanoids and a diterpene (8) in collected samples might be responsible for such activities [98].

Characterization of Mediterranean propolis samples' constituents from four different regions (Algeria, Greece, Croatia, and Cyprus), determined that Greek propolis composition, with antibacterial and antioxidant properties, is different from other common European propolis samples and has a higher percentage of diterpenoids $(\mathbf{3}, \mathbf{6}, \mathbf{9}$, and $\mathbf{1 0})$ while having lower amounts of phenolic compounds [99].

From studies on Libyan propolis, two bioactive diterpenes (11-13) were isolated, elucidated, and later their antiparasitic activities were evaluated to overcome African Trypanosomiasis. These diterpenoids showed almost the same activity with $\mathrm{IC}_{50 \mathrm{~s}}$ of around $1.5 \mu \mathrm{g} / \mathrm{mL}$ against Trypanosoma brucei. Furthermore, these bioactive Libyan propolis constituents were studied for leishmaniosis, and they exhibited inhibitory activity against infection of macrophages with Leishmania donovani $\left(\mathrm{IC}_{50 \mathrm{~s}} 5-22 \mu \mathrm{g} / \mathrm{mL}\right)$ [100].

In a chemical profiling of Saudi Arabian propolis samples, diterpenoids (14) and (15) were characterized and their botanical sources were identified as Psiadia arabica Jaub. et Spac and Psiadia punctulata DC., respectively. Compounds 14 and 15 were evaluated against local skin mycobacterium (Mycobacterium marinum) and sleeping sickness protozoan (Trypanosoma brucei) and both presented activities [101].

Propolis samples collected from different areas of Iraq were analysed and the results revealed there exist clerodanoids, a type of terpenes structurally similar to labdane diterpenes, in their constitutions. The samples showed antioxidant properties [102].

Exploiting gas chromatographic mass-spectroscopy (GC-MS), propolis samples having antibacterial activities collected from Malta were analysed, and numbers of diterpenes were categorized [91], previously published in another Mediterranean propolis type from Greece [90,91]. Ferula communis L. was proposed as this type of Malta propolis botanical source. The results showed the highest portions belong to compounds 3, 6, 9-11, and 16, while compounds 17-19 were in the minority [91]. Other diterpenoids found in this type of propolis are compounds $\mathbf{1}, \mathbf{1 2}, \mathbf{1 3}$, and 20-31.

Six diterpenes were isolated from Greek propolis in 2010. They demonstrated anticancer effects and, in an investigation done on this type of propolis, the isolated diterpenes had the activities against human colon adenocarcinoma cells (HT-29) with the lowest side effects on normal cells and introducing manool (32) $\left(\mathrm{IC}_{50}=6.5 \mu \mathrm{g} / \mathrm{mL}\right)$ as the most active among them [72].

In the comprehensive study done on the Greek propolis from Cretan the diterpenes have been isolated and elucidated. Diterpenoids (9, 23-25, and 33-36) were reported for the first time from propolis. These compounds were tested against some Gram-positive and -negative bacteria. The results exhibited antibacterial activity. All tested compounds showed a broad spectrum of antibacterial activity, while diterpenes (3) and (23) had the highest activity against all examined bacteria. The minimum inhibitory concentrations (MICs) range of these compounds against the tested bacteria was from 0.07 to $1.80 \mathrm{mg} / \mathrm{mL}$. Furthermore, the synergistic effect was noted for compounds 35 and 36 ( $E$ and $Z$ configurations); hence, the combination of them had a profound activity against the Gram-positive bacteria [103].

In the study on the main botanical source of green propolis collected from Brazil, Baccharis dracunculifolia, for the first time a clerodanoid (37) was identified. Although this type of propolis showed antibacterial activity, compound 37 did not exhibit any significant antimicrobial properties [104]. The results were consistent with previous comprehensive liquid chromatography mass-spectroscopy (LC-MS) study on this type of propolis sample, plus the stated botanical source, shedding light on their chemical constituents profile, including the existence of diterpenoids (especially labdanoids) [105]. Extraction on Brazilian propolis samples showed diterpenoids were mostly found in methanolic extract, and only negligible amount of diterpenoids were traced in water extract; this is quite expected due to their non-polar characteristics [106].

Study on the European propolis extraction from Greece resulted in identification of diterpenoids $3,6,11,12$, and 19-22. The isolated compounds were screened for their antibacterial and antifungal 
activities. They showed activity against both Gram-positive and -negative bacteria; however, compound 3 manifested strong antibacterial activity against Gram-positive bacteria, especially Staphylococcus spp, in comparison with references, which confirmed totarol's (3) reputation as an antibacterial agent. Weak effects were reported from antifungal activity testings [107]. It is worth mentioning that a study of European propolis was directed to the isolation of diterpenes 6, 10, and 21 from an Italian propolis type with antimicrobial properties [108]. The same presence of diterpenoids in Italian propolis samples was also stated in a 2002 GC-MS analytical study on a Sicilian type [109].

The study on a Central America propolis type reported two glycoside diterpenes (38 and 39) sourcing from El Salvador propolis samples presenting the noteworthy antibacterial effects on Staphylococcus aureus with the minimum inhibitory dose almost three-times less than the obtained lethal dose from a toxicity bioassay [92].

Brazilian propolis anti-hepatotoxic methanolic extract resulted in the isolation of labdanoids $(12,13,40$, and 41). In more details, compounds 12 and 40 showed the highest antihepatotoxic activities ( $\mathrm{IC}_{50 \mathrm{~s}} 80$ and $45 \mu \mathrm{M}$, respectively), and this activity might be linked to diterpenoids' healing effects observed on D-galactosamine/TNF- $\alpha$-induced hepatic damage models [110-112]. The isolated compounds were also evaluated for the anti-helicobacter pylori activity, and compound $\mathbf{4 1}$ was active against all tested strains, while compound $\mathbf{1 3}$ limited its activity to only one strain [110]. There is a study which showed the isolated diterpenoid from Brazilian Meliponinae with antibacterial activity against Gram-positive bacteria, particularly against Staphylococcus aureus. Moreover, the samples from this type of propolis, which contained high concentrations of diterpenes, showed cytotoxic activities [113].

Interestingly, although most of reports about propolis samples' bioactive constituents show Apis mellifera species play the key role in the sample collection procedure, a study reported tetra-cyclic diterpenoids (42-44) from propolis samples supplied by Brazilian native stingless bees (Meliponini). Compound 42 only showed antimicrobial property [114]. Two active clerodane diterpenes (45 in $E$ configuration and 46 in $Z$ configuration) from Brazilian propolis had been isolated, elucidated, and assessed for their human hepatocellular carcinoma cell cytotoxicity [115].

Additionally, a promising antitumor diterpene (47) isolated and elucidated from Brazilian propolis showed significant effects, such as in vivo antitumor activity on mice skin [74], in vitro cytotoxic activities against hepatocellular, renal cell carcinoma, lung cancerous cells [116], and tumoricidal activity against HeLa 53 Cells ( $\mathrm{IC}_{50} 87 \mu \mathrm{g} / \mathrm{mL}$ ) [117].

As the first review report about diterpenoids sequestered from propolis, it is worth mentioning that labdanoids $(\mathbf{6}, \mathbf{1 0}, \mathbf{1 3}$, and 16) were purified from a Brazilian propolis type, with the same pattern for diterpenes found in Araucaria genus members, which provides a clue to its botanical source [118].

\section{Discussions and Conclusions}

Most diterpenes isolated from propolis possess antibacterial and cytotoxic activities; for that reason, in this section these two activities have been centred on and the mechanisms of action are discussed. Regarding the cytotoxic and anticancer characteristics of diterpenes obtained from propolis, some hypotheses have been generated. In the study about a diterpenoid from Brazilian propolis which had cytotoxic effects against human hepatocellular carcinoma, the growth of the malignant cells has been blocked by $\alpha$-DNA polymerase inhibition [119]. Moreover, compound 47 (PMS-1) showed its antitumor activity through the inhibition of DNA synthesis. There are two pathways for this bioactivity. The first one is that by inhibiting the DNA synthesis in the de novo pathway, the occurrence of tumours has been decreased. In the second pathway, the salvage pathway, through reducing DNA synthesis, the growth of the tumours has been suppressed [74]. Furthermore, in the experiment on the cytotoxicity activity of manool (32), one of the most active diterpenes from Greek propolis, it had been exhibited that the cell cycle of the cancer cells was blocked at the $\mathrm{G}_{2} / \mathrm{M}$ stage [72]. The same mechanism has been reported for the propolis collected in Southern Brazil [120]. 
One of the known isolated diterpenes from propolis which had a significant antibacterial activity is totarol (3). Even though the mechanism of action of this compound is not clear but there are some proposed mechanisms for this activity [121]. One of these suggested mechanisms is that, the consumption of oxygen in bacteria cells is inhibited by this diterpene, and also totarol (3), can disturb the electron transport and respiratory pathway in the oxidation of bacteria membranes by inhibiting NADH-related enzymes, such as NADH-cytochrome C reductase, NADH-DPIP reductase, and NADH-CoQ reductase [122], although this hypothesis is not very robust regarding the activity of totarol (3) against anaerobic bacteria [123]. Moreover, there have been studies conducted on antibacterial activity against methicillin-resistant Staphylococcus aureus [124-126] and the main suggested mechanism for this activity is interfering with penicillin binding protein 2 expression [127]. This diterpene and its derivatives may affect the synthesizing of the adenosine triphosphate in bacteria [128], and also destabilizing the membrane integrity by decreasing the intermolecular forces of the bacteria phospholipid bilayer structure [129-131]. In 2007 it was stated that through inhibition of filamenting temperature-sensitive mutant $Z$ (FtsZ) protein, the protein which moves to the division site throughout cell division in prokaryotic cells and is vital to construct a cell wall [132], the growth of the Gram-positive bacteria was blocked [133].

In summary, this review focused on biologically- and pharmacologically-active diterpenes obtained from propolis as the natural source. We have outlined the geographical locations of the recognized sources, and their bioactivities, plus the probable mechanisms of actions. Diterpene nuclei isolated from propolis are attractive for medicinal chemists to design and discover novel therapeutic agents owing to their less toxic side effects. By means of synthesis and applying the required changes in the diterpene core structures their bioactivities might be enhanced. For instance, by studying and synthesis of the different derivatives of totarol, alterations of the aromatic ring moieties, it was manifested that a hydroxyl moiety is crucial for existing antibacterial activity [134]. Furthermore, in vitro examinations illustrated that inserting moieties on the aromatic ring, apart from the hydroxyl group, decreases the antibacterial properties of this diterpenoid class [135]. Since the isolation of diterpenes from propolis gives a higher yield and easier access than the plant source, the isolated diterpenes can be used in the semi-synthesis of novel leads. As an example, the studies done on labdane-type diterpenes and clerodane diterpenes illustrated that the derivatives of these type of diterpenes can act as novel antimalarial, antileishmanial, and anti-inflammatory drugs [136,137]. Therefore, diterpenes are recognized and well-known to have a broad range of structures with different moieties which have significant effects on the critical medicinal targets for prevention and treatment of several diseases.

Despite the clear progress in natural products there are not enough in vivo studies on the claimed isolated diterpenes; thus, further in vivo examinations of these potent and safe agents are inevitable. Additionally, a systematic investigation of these type of compounds can be useful. To come to the point, this review is presented to display the importance of propolis as a novel and less toxic bioactive source of diterpenes.

Acknowledgments: The authors wish to thank supports from the University of Sydney and members of their respective research groups for a supportive environment and their collegiality.

Author Contributions: Noushin Aminimoghadamfarouj conducted the literature bibliography, preparing the data, and writing the draft; Noushin Aminimoghadamfarouj and Alireza Nematollahi wrote the paper. The authors contributed with reading, editing, and revising of this manuscript and approved the final version.

Conflicts of Interest: The authors declare no conflict of interest.

\section{References}

1. Crane, E. A short history of knowledge about honey bees (Apis) up to 1,800. Bee world 2004, 85, 6-11. [CrossRef]

2. Harissis, H.V.; Harissis, A.V. Apiculture in the Prehistoric Aegean: Minoan and Mycenaean Symbols Revisited; Hedges: Oxford, UK, 2009. 
3. Crane, E. Recent research on the world history of beekeeping. Bee World 1999, 80, 174-186. [CrossRef]

4. Da Veiga, P.A.S. Health and Medicine in Ancient Egypt: Magic and Science; Archaeopress: Oxford, UK, 2009.

5. Maruhashi, E. L-Mesitran ${ }^{\circledR}$ in the management of canine otitis externa. Ph.D. dissertation, Universidade de Lisboa, Faculdade de Medicina Veterinária, Portugal, 2015.

6. Bankova, V.S.; Popov, S.S.; Marekov, N.L. Isopentenyl cinnamates from poplar buds and propolis. Phytochemistry 1989, 28, 871-873. [CrossRef]

7. Ruttner, F. Biogeography and Taxonomy of Honeybees; Springer: Berlin, German, 1988.

8. Bunney, M.H. Contact dermatitis in beekeepees due to propolis (bee glue). Br. J. Der. 1968, 80, 17-23. [CrossRef]

9. Bankova, V. Chemical diversity of propolis and the problem of standardization. J. Ethnopharmacol. 2005, 100, 114-117. [CrossRef] [PubMed]

10. Castaldo, S.; Capasso, F. Propolis, an old remedy used in modern medicine. Fitoterapia 2002, 73 (Suppl. S1), S1-S6. [CrossRef]

11. Meyer, W.; Ulrich, W. "Propolis Bees" and their activities. Bee World 2015, 37, 25-36. [CrossRef]

12. Ghisalberti, E.L. Propolis: A review. Bee World 1979, 60, 59-84. [CrossRef]

13. Starostensko, E.V. Propolization by bees of various races. Pchelovodsvo 1968, 88, 30.

14. Kuropatnicki, A.K.; Szliszka, E.; Krol, W. Historical aspects of propolis research in modern times. Evid. Based Complement. Alternat. Med. 2013. [CrossRef] [PubMed]

15. Krell, R. Value-Added Products from Beekeeping; Food \& Agriculture Org: Quebec city, QC, Canada, 1996.

16. Marcucci, M.C. Propolis: Chemical composition, biological properties and therapeutic activity. Apidologie 1995, 26, 83-99. [CrossRef]

17. Bankova, V.S.; Castro, S.L.D.; Marcucci, M.C. Propolis: Recent advances in chemistry and plant origin. Apidologie 2000, 31, 3-15. [CrossRef]

18. Abu-Mellal, A.; Koolaji, N.; Duke, R.K.; Tran, V.H.; Duke, C.C. Prenylated cinnamate and stilbenes from Kangaroo Island propolis and their antioxidant activity. Phytochemistry 2012, 77, 251-259. [CrossRef] [PubMed]

19. Zhang, T.; Omar, R.; Siheri, W.; Al Mutairi, S.; Clements, C.; Fearnley, J.; Edrada-Ebel, R.; Watson, D. Chromatographic analysis with different detectors in the chemical characterisation and dereplication of African propolis. Talanta 2014, 120, 181-190. [CrossRef] [PubMed]

20. Trusheva, B.; Popova, M.; Bankova, V.; Simova, S.; Marcucci, M.C.; Miorin, P.L.; da Rocha Pasin, F.; Tsvetkova, I. Bioactive constituents of brazilian red propolis. Evid. Based Complement. Alternat. Med. 2006, 3, 249-254. [CrossRef] [PubMed]

21. Sforcin, J.M.; Bankova, V. Propolis: Is there a potential for the development of new drugs? J. Ethnopharmacol. 2011, 133, 253-260. [CrossRef] [PubMed]

22. Politi, M.; Braca, A.; de Tommasi, N.; Morelli, I.; Manunta, A.; Battinelli, L.; Mazzanti, G. Antimicrobial diterpenes from the seeds of Cephalotaxus harringtonia var. drupacea. Planta Med. 2003, 69, 468-470. [PubMed]

23. Zeng, H.H.; Tu, P.F.; Zhou, K.; Wang, H.; Wang, B.H.; Lu, J.F. Antioxidant properties of phenolic diterpenes from Rosmarinus officinalis. Acta Pharmacol. Sin. 2001, 22, 1094-1098. [PubMed]

24. Premprasert, C.; Tewtrakul, S.; Plubrukarn, A.; Wungsintaweekul, J. Anti-inflammatory activity of diterpenes from Croton stellatopilosus on LPS-induced RAW264.7 cells. J. Nat. Med. 2013, 67, 174-181. [CrossRef] [PubMed]

25. Rasoamiaranjanahary, L.; Marston, A.; Guilet, D.; Schenk, K.; Randimbivololona, F.; Hostettmann, K. Antifungal diterpenes from Hypoestes serpens (Acanthaceae). Phytochemistry 2003, 62, 333-337. [CrossRef]

26. Lee, J.J.; Jin, Y.R.; Lee, J.H.; Yu, J.Y.; Han, X.H.; Oh, K.W.; Hong, J.T.; Kim, T.J.; Yun, Y.P. Antiplatelet activity of carnosic acid, a phenolic diterpene from Rosmarinus officinalis. Planta Med. 2007, 73, 121-127. [CrossRef]

27. Greay, S.; Hammer, K. Recent developments in the bioactivity of mono- and diterpenes: Anticancer and antimicrobial activity. Phytochem. Rev. 2011, 14, 1-6. [CrossRef]

28. Odek-Ogunde, M.; Rajab, M.S. Antihypertensive effect of the clerodane diterpene ajugarin I on experimentally hypertensive rats. East Afr. Med. J. 1994, 71, 587-590.

29. Porto, T.S.; Rangel, R.; Furtado, N.A.; de Carvalho, T.C.; Martins, C.H.; Veneziani, R.C.; da Costa, F.B.; Vinholis, A.H.; Cunha, W.R.; Heleno, V.C.; et al. Pimarane-type diterpenes: Antimicrobial activity against oral pathogens. Molecules 2009, 14, 191-199. [CrossRef] 
30. Aceret, T.L.; Coll, J.C.; Uchio, Y.; Sammarco, P.W. Antimicrobial activity of the diterpenes flexibilide and sinulariolide derived from Sinularia flexibilis Quoy and Gaimard 1833 (Coelenterata: Alcyonacea, Octocorallia). Comp. Biochem. Physiol. C. Pharmacol. Toxicol. Endocrinol. 1998, 120, 121-126. [CrossRef]

31. Reina, E.; Puentes, C.; Rojas, J.; Garcia, J.; Ramos, F.A.; Castellanos, L.; Aragon, M.; Ospina, L.F. Fuscoside E: A strong anti-inflammatory diterpene from Caribbean octocoral Eunicea fusca. Bioorg. Med. Chem. Lett. 2011, 21, 5888-5891. [CrossRef]

32. Salah, M.A.; Bedir, E.; Toyang, N.J.; Khan, I.A.; Harries, M.D.; Wedge, D.E. Antifungal clerodane diterpenes from Macaranga monandra (L) Muell. et Arg. (Euphorbiaceae). J. Agric. Food Chem. 2003, 51, 7607-7610. [CrossRef]

33. Tirapelli, C.R.; Ambrosio, S.R.; de Oliveira, A.M.; Tostes, R.C. Hypotensive action of naturally occurring diterpenes: A therapeutic promise for the treatment of hypertension. Fitoterapia 2010, 81, 690-702. [CrossRef]

34. Martin, Y.C. A bioavailability score. J. Med. Chem. 2005, 48, 3164-3170. [CrossRef]

35. Yoshida, F.; Topliss, J.G. QSAR model for drug human oral bioavailability. J. Med. Chem. 2000, 43, 2575-2585. [CrossRef]

36. Boehm, M.; Fuenfschilling, P.C.; Krieger, M.; Kuesters, E.; Struber, F. An improved manufacturing process for the antimalaria drug coartem. Part I. Org. Process Res. Dev. 2007, 11, 336-340. [CrossRef]

37. Nematollahi, A.; Aminimoghadamfarouj, N.; Wiart, C. Reviews on 1,4-naphthoquinones from Diospyros L. J. Asian Nat. Prod. Res. 2012, 14, 80-88. [CrossRef]

38. Aminimoghadamfarouj, N.; Nematollahi, A.; Wiart, C. Annonaceae: Bio-resource for tomorrow's drug discovery. J. Asian Nat. Prod. Res. 2011, 13, 465-476. [CrossRef]

39. Meresta, L.; Meresta, T. Effect of $\mathrm{pH}$ on bactericidal activity of propolis. Bull. Veterina. Inst. Pulawy 1980, 24, 21-25.

40. Gonzales, G.V.; Hernandez, N.R.; Vera, C.M. Comparative study of the antimicrobial activity of propolis and that of antibiotics and conventional disinfectants. Ciencia Y Tenica en la Agriculura Apiculura 1985, 1, $23-36$.

41. Grange, J.M.; Davey, R.W. Antibacterial properties of propolis (bee glue). J. R. Soc. Med. 1990, 83, 159-160.

42. Obregón Fuentes, A.; Rojas Hernández, N. Antimicrobial action of alcoholic extracts of propolis. Revista Cubana de Farmacia 1990, 24, 34-44.

43. Ibragimova, A.; Pankratova, N. Combined antimicrobial effect of propolis and antibiotics on pathogenic staphylococci. Sbornik Nauchnykh Trudov, Kazanskii Veterinarnyi Institute 1983, 43, 46.

44. Meresta, L.; Meresta, T. An attempt to use the extract from propolis in the treatment of mastitis of cows. Med. Weter. 1985, 41, 489-492.

45. Maksimova-Todorova, V.; Manolova, N.; Gegova, G.; Serkedzhieva, I.; Uzunov, S. Antiviral action of fractions isolated from propolis. Acta Microbiol. Bulg. 1985, 17, 79-85.

46. Amoros, M.; Sauvager, F.; Girre, L.; Cormier, M. In vitro antiviral activity of propolis. Apidologie 1992, 23, 231-240. [CrossRef]

47. Bankova, V.; Galabov, A.S.; Antonova, D.; Vilhelmova, N.; di Perri, B. Chemical composition of propolis extract $\mathrm{ACF}(\mathrm{R})$ and activity against herpes simplex virus. Phytomedicine 2014, 21, 1432-1438. [CrossRef]

48. Chiang, L.C.; Chiang, W.; Chang, M.Y.; Ng, L.T.; Lin, C.C. Antiviral activity of Plantago major extracts and related compounds in vitro. Antiviral Res. 2002, 55, 53-62. [CrossRef]

49. Lyu, S.Y.; Rhim, J.Y.; Park, W.B. Antiherpetic activities of flavonoids against herpes simplex virus type 1 (HSV-1) and type 2 (HSV-2) in vitro. Arch. Pharm. Res. 2005, 28, 1293-1301. [CrossRef]

50. Elias, D.; Beazely, M.; Kandepu, N. Bioactivities of chalcones. Curr. Med. Chem. 1999, 6, 1125.

51. Suárez, B.; Álvarez, Á.L.; García, Y.D.; del Barrio, G.; Lobo, A.P.; Parra, F. Phenolic profiles, antioxidant activity and in vitro antiviral properties of apple pomace. Food Chem. 2010, 120, 339-342. [CrossRef]

52. Gravina, H.D.; Tafuri, N.F.; Silva Junior, A.; Fietto, J.L.; Oliveira, T.T.; Diaz, M.A.; Almeida, M.R. In vitro assessment of the antiviral potential of trans-cinnamic acid, quercetin and morin against equid herpesvirus 1. Res. Vet. Sci. 2011, 91, e158-e162. [CrossRef]

53. Millet-Clerc, J.; Simeray, J.; Michel, D.; Chaumont, J. Antifungal properties of propolis against fungi causing mycoses. J. Mycol. Med. 1987, 15, 517-521.

54. Holderna, E.; Kedzia, B. Investigation upon the combined action of propolis and antimycotic drugs on Candida albicans. Herba Polo. 1987, 33, 145-151. 
55. Silici, S.; Koc, N.A.; Ayangil, D.; Cankaya, S. Antifungal activities of propolis collected by different races of honeybees against yeasts isolated from patients with superficial mycoses. J. Pharmacol. Sci. 2005, 99, 39-44. [CrossRef]

56. Kasote, D.; Ahmad, A.; Chen, W.; Combrinck, S.; Viljoen, A. HPTLC-MS as an efficient hyphenated technique for the rapid identification of antimicrobial compounds from propolis. Phytochem. Lett. 2015, 11, 326-331. [CrossRef]

57. Lori, G. Fungicidal effect of propolis in bovine dermatomycosis. Industria Apícola 1990, 1, 38-43.

58. Yang, S.Z.; Peng, L.T.; Su, X.J.; Chen, F.; Cheng, Y.J.; Fan, G.; Pan, S.Y. Bioassay-guided isolation and identification of antifungal components from propolis against Penicillium italicum. Food Chem. 2011, 127, 210-215. [CrossRef]

59. Almutairi, S.; Eapen, B.; Chundi, S.M.; Akhalil, A.; Siheri, W.; Clements, C.; Fearnley, J.; Watson, D.G.; Edrada-Ebel, R. New anti-trypanosomal active prenylated compounds from African propolis. Phytochem. Lett. 2014, 10, 35-39. [CrossRef]

60. Hegazi, A.; Abd El Hady, F.; Shalaby, H. Egyptian propolis: 4-Chemical Composition of Siwa Oasis Propolis with Reference to its Effect on Fasciola Gigantica Eggs. In Proceedings of the 1st International Forum on Apitherapy, Athens, Greece, October 2006; pp. 31-32.

61. Higashi, K.; de Castro, S. Propolis extracts are effective against Trypanosoma cruzi and have an impact on its interaction with host cells. J. Ethnopharmacol. 1994, 43, 149-155. [CrossRef]

62. Miyares, C.; Hollands, I.; Castaneda, C.; Gonzalez, T.; Fragoso, T.; Curras, R.; Soria, C. Clinical trial with a preparation based on propolis "propolisina" in human giardiasis. Acta Gastroenterol. Latinoam. 1987, 18, 195-201.

63. Starzyk, J.; Scheller, S.; Szaflarski, J.; Moskwa, M.; Stojko, A. Biological properties and clinical application of propolis. II. Studies on the antiprotozoan activity of ethanol extract of propolis. Arzneimittel-Forschung 1976, 27, 1198-1199.

64. Torres, D.; Hollands, I.; Palacios, E. Effect of an alcoholic extract of propolis on the in vitro growth of Giardia lamblia. Rev. Cuba. Cienc. Vet. 1990, 21, 15-19.

65. Salas, A.L.; Alberto, M.R.; Zampini, I.C.; Cuello, A.S.; Maldonado, L.; Ríos, J.L.; Schmeda-Hirschmann, G.; Isla, M.I. Biological activities of polyphenols-enriched propolis from Argentina arid regions. Phytomedicine 2016, 23, 27-31. [CrossRef]

66. Bockmuehl, D.; Breves, R.; Weide, M.; Stumpe, S.; Heinzel, M. Adhesion inhibition of fungi. WO2003051125A1, 2003.

67. Wang, K.; Hu, L.; Jin, X.L.; Ma, Q.X.; Marcucci, M.C.; Netto, A.A.L.; Sawaya, A.C.H.F.; Huang, S.; Ren, W.K.; Conlon, M.A.; et al. Polyphenol-rich propolis extracts from China and Brazil exert anti-inflammatory effects by modulating ubiquitination of TRAF6 during the activation of NF-kB. J. Funct. Foods 2015, 19, 464-478. [CrossRef]

68. Cavendish, R.L.; de Souza Santos, J.; Neto, R.B.; Paixao, A.O.; Oliveira, J.V.; de Araujo, E.D.; Silva, A.A.B.E.; Thomazzi, S.M.; Cardoso, J.C.; Gomes, M.Z. Antinociceptive and anti-inflammatory effects of Brazilian red propolis extract and formononetin in rodents. J. Ethnopharmacol. 2015, 173, 127-133.

69. Valenzuela-Barra, G.; Castro, C.; Figueroa, C.; Barriga, A.; Silva, X.; de Las Heras, B.; Hortelano, S.; Delporte, C. Anti-inflammatory activity and phenolic profile of propolis from two locations in Region Metropolitana de Santiago, Chile. J. Ethnopharmacol. 2015, 168, 37-44. [CrossRef]

70. Funakoshi-Tago, M.; Okamoto, K.; Izumi, R.; Tago, K.; Yanagisawa, K.; Narukawa, Y.; Kiuchi, F.; Kasahara, T.; Tamura, H. Anti-inflammatory activity of flavonoids in Nepalese propolis is attributed to inhibition of the IL-33 signaling pathway. Int. Immunopharmacol. 2015, 25, 189-198. [CrossRef]

71. Li, F.; Awale, S.; Tezuka, Y.; Kadota, S. Cytotoxic constituents from Brazilian red propolis and their structure-activity relationship. Bioorg. Med. Chem. 2008, 16, 5434-5440. [CrossRef]

72. Pratsinis, H.; Kletsas, D.; Melliou, E.; Chinou, I. Antiproliferative activity of Greek propolis. J. Med. Food 2010, 13, 286-290. [CrossRef]

73. Matsuno, T.; Saito, M.; Matsumoto, Y.; Morikawa, J. A new benzo- $\gamma$-pyran derivative isolated from propolis. Z. Naturforsch. C 1998, 53, 1037-1039.

74. Mitamura, T.; Matsuno, T.; Sakamoto, S.; Maemura, M.; Kudo, H.; Suzuki, S.; Kuwa, K.; Yoshimura, S.; Sassa, S.; Nakayama, T. Effects of a new clerodane diterpenoid isolated from propolis on chemically induced skin tumors in mice. Anticancer Res. 1995, 16, 2669-2672. 
75. Conti, B.J.; Búfalo, M.C.; Golim, M.D.A.; Bankova, V.; Sforcin, J.M. Cinnamic acid is partially involved in propolis immunomodulatory action on human monocytes. Evid. Based Complement. Alternat. Med. 2013. [CrossRef]

76. Orsatti, C.L.; Sforcin, J.M. Propolis immunomodulatory activity on TLR-2 and TLR-4 expression by chronically stressed mice. Nat. Prod. Res. 2012, 26, 446-453. [CrossRef]

77. Sampietro, D.A.; Sampietro Vattuone, M.M.; Vattuone, M.A. Immunomodulatory activity of Apis mellifera propolis from the North of Argentina. Food Sci. Tech. 2016, 70, 9-15. [CrossRef]

78. Gritsenko, V.I.; Tikhonov, O.I.; Priakhin, O.R. Study of the polysaccharide preparation, propolis. Farm. Zh. 1977, 92-93.

79. Ikeno, K.; Ikeno, T.; Miyazawa, C. Effects of propolis on dental-caries in rats. Caries Res. 1991, 25, 347-351. [CrossRef]

80. Hay, K.D.; Greig, D.E. Propolis allergy: A cause of oral mucositis with ulceration. Oral Surg. Oral Med. Oral Pathol. 1990, 70, 584-586. [CrossRef]

81. Rudzki, E.; Grzywa, Z.; Pomorski, Z. New data on dermatitis from propolis. Contact Derm. 1985, 13, $198-199$.

82. Rudzki, E.; Grzywa, Z. Dermatitis from propolis. Contact Derm. 1983, 9, 40-45. [CrossRef]

83. Hausen, B.; Wollenweber, E.; Senff, H.; Post, B. Propolis allergy. Contact Derm. 1987, 17, 163-170. [CrossRef]

84. Dickschat, J.S. Isoprenoids in three-dimensional space: The stereochemistry of terpene biosynthesis. Nat. Prod. Rep. 2011, 28, 1917-1936. [CrossRef]

85. Gilbert, K. Plant secondary metabolism. Plant Growth Regul. 2001, 34, 149. [CrossRef]

86. Pan, L.; Blanco, E.C.; Kinghorn, A.D. Plant-derived natural products as leads for drug discovery. In Plant-Derived Natural Products; Osbourn, A.E., Lanzotti, V., Eds.; Springer: New York, NY, USA, 2009; pp. 547-567.

87. Righi, A.A.; Negri, G.; Salatino, A. Comparative chemistry of propolis from eight brazilian localities. Evid. Based Complement. Alternat. Med. 2013, 2013. [CrossRef]

88. Burdock, G.A. Review of the biological properties and toxicity of bee propolis (propolis). Food Chem. Toxicol. 1998, 36, 347-363. [CrossRef]

89. Araujo, M.J.; Mattar, N.S.; Reis, A.S.; Serra, I.C.; Fialho, E.M.; Assuncao, A.K.; Dutra, R.P.; Nogueira, A.M.; Liberio, S.A.; Guerra, R.N.; et al. Pharmacognostic and acute toxicological evaluation of Scaptotrigona aff. postica propolis extract in pre-clinical assays. Nat. Prod. Res. 2011, 25, 1037-1046. [CrossRef]

90. Popova, M.P.; Graikou, K.; Chinou, I.; Bankova, V.S. GC-MS profiling of diterpene compounds in Mediterranean propolis from Greece. J. Agric. Food Chem. 2010, 58, 3167-3176. [CrossRef]

91. Popova, M.; Trusheva, B.; Antonova, D.; Cutajar, S.; Mifsud, D.; Farrugia, C.; Tsvetkova, I.; Najdenski, H.; Bankova, V. The specific chemical profile of Mediterranean propolis from Malta. Food Chem. 2011, 126, 1431-1435. [CrossRef]

92. Popova, M.; Bankova, V.; Tsvetkova, I.; Naydenski, C.; Silva, M.V. The first glycosides isolated from propolis: Diterpene rhamnosides. Z. Naturforsch. C J. Biosci. 2001, 56, 1108-1111. [CrossRef]

93. Elnakady, Y.A.; Rushdi, A.I.; Franke, R.; Abutaha, N.; Ebaid, H.; Baabbad, M.; Omar, M.O.; Al Ghamdi, A.A. Characteristics, chemical compositions and biological activities of propolis from Al-Bahah, Saudi Arabia. Sci. Rep. 2017, 7, 41453. [CrossRef]

94. El-Guendouz, S.; Aazza, S.; Lyoussi, B.; Bankova, V.; Lourenco, J.P.; Costa, A.M.; Mariano, J.F.; Miguel, M.G.; Faleiro, M.L. Impact of biohybrid magnetite nanoparticles and Moroccan propolis on adherence of methicillin resistant strains of staphylococcus aureus. Molecules 2016, 21, 1208. [CrossRef]

95. Popova, M.; Lyoussi, B.; Aazza, S.; Antunes, D.; Bankova, V.; Miguel, G. Antioxidant and $\alpha$-glucosidase inhibitory properties and chemical profiles of Moroccan propolis. Nat. Prod. Commun. 2015, 10, 1961-1964.

96. Tazawa, S.; Arai, Y.; Hotta, S.; Mitsui, T.; Nozaki, H.; Ichihara, K. Discovery of a novel diterpene in brown propolis from the State of Parana, Brazil. Nat. Prod. Commun. 2016, 11, 201-205.

97. Tazawa, S.; Arai, Y.; Hotta, S.; Ichihara, K. Novel diterpene, its production method, antitumor agent containing the same, propolis extract, and method for evaluation of propolis extract. JP2015205824A, 2015.

98. Nina, N.; Quispe, C.; Jimenez-Aspee, F.; Theoduloz, C.; Feresin, G.E.; Lima, B.; Leiva, E.; Schmeda-Hirschmann, G. Antibacterial activity, antioxidant effect and chemical composition of propolis from the region del maule, central Chile. Molecules 2015, 20, 18144-18167. [CrossRef] 
99. Graikou, K.; Popova, M.; Gortzi, O.; Bankova, V.; Chinou, I. Characterization and biological evaluation of selected Mediterranean propolis samples. Is it a new type? Lwt-Food Sci. Technol. 2016, 65, 261-267. [CrossRef]

100. Siheri, W.; Igoli, J.O.; Gray, A.I.; Nasciemento, T.G.; Zhang, T.; Fearnley, J.; Clements, C.J.; Carter, K.C.; Carruthers, J.; Edrada-Ebel, R.; et al. The isolation of antiprotozoal compounds from Libyan propolis. Phytother. Res. 2014, 28, 1756-1760. [CrossRef]

101. Almutairi, S.; Edrada-Ebel, R.; Fearnley, J.; Igoli, J.O.; Alotaibi, W.; Clements, C.J.; Gray, A.I.; Watson, D.G. Isolation of diterpenes and flavonoids from a new type of propolis from Saudi Arabia. Phytochem. Lett. 2014, 10, 160-163. [CrossRef]

102. Sulaiman, G.M.; Al Sammarrae, K.W.; Ad’hiah, A.H.; Zucchetti, M.; Frapolli, R.; Bello, E.; Erba, E.; D'Incalci, M.; Bagnati, R. Chemical characterization of Iraqi propolis samples and assessing their antioxidant potentials. Food Chem. Toxicol. 2011, 49, 2415-2421. [CrossRef]

103. Popova, M.P.; Chinou, I.B.; Marekov, I.N.; Bankova, V.S. Terpenes with antimicrobial activity from Cretan propolis. Phytochemistry 2009, 70, 1262-1271. [CrossRef]

104. Filho, A.A.D.S.; de Sousa, J.P.B.; Soares, S.; Furtado, N.A.J.C.; Silva, M.L.A.E.; Cunha, W.R.; Gregorio, L.E.; Nanayakkara, N.R.D.; Bastos, J.K. Antimicrobial activity of the extract and isolated compounds from Baccharis dracunculifolia D.C. (Asteraceae). Z. Naturforsch. C Bio. Sci. 2008, 63, 40-46.

105. Midorikawa, K.; Banskota, A.H.; Tezuka, Y.; Matsushige, K.; Message, D.; Huertas, A.A.G.; Kadota, S. Buds of Baccharis dracunculifolia: Potent source of biologically active caffeoylquinic acids and labdane-type diterpenes of Brazilian propolis. Yakugaku Zasshi 2003, 20, 187-194.

106. Midorikawa, K.; Banskota, A.H.; Tezuka, Y.; Nagaoka, T.; Matsushige, K.; Message, D.; Huertas, A.A.; Kadota, S. Liquid chromatography-mass spectrometry analysis of propolis. Phytochem. Anal. 2001, 12, 366-373. [CrossRef]

107. Melliou, E.; Chinou, L. Chemical analysis and antimicrobial activity of Greek propolis. Planta Med. 2004, 70, 515-519. [CrossRef]

108. Trusheva, B.; Popova, M.; Bankova, V.; Tsvetkova, I.; Naydenski, C.; Sabatini, A.G. A new type of European propolis, containing bioactive labdanes. Riv. Ital. EPPOS 2003, 36, 3-7.

109. Bankova, V.; Popova, M.; Bogdanov, S.; Sabatini, A.G. Chemical composition of European propolis: Expected and unexpected results. Z. Naturforsch. C 2002, 57, 530-533. [CrossRef]

110. Banskota, A.H.; Tezuka, Y.; Adnyana, I.K.; Ishii, E.; Midorikawa, K.; Matsushige, K.; Kadota, S. Hepatoprotective and anti-Helicobacter pylori activities of constituents from Brazilian propolis. Phytomedicine 2001, 8, 16-23. [CrossRef]

111. Leist, M.; Gantner, F.; Bohlinger, I.; Germann, P.G.; Tiegs, C.; Wendel, A. Murine hepatocyte apoptosis induced in-vitro and in-vivo by TNF- $\alpha$ requires transcriptional arrest. J. Immunol. 1994, 153, 1778-1788.

112. Gonzalez, R.; Corcho, I.; Remirez, D.; Rodriguez, S.; Ancheta, O.; Merino, N.; Gonzalez, A.; Pascual, C. Hepatoprotective effects of propolis extract on carbon tetrachloride-induced liver-injury in rats. Phytother. Res. 1995, 9, 114-117. [CrossRef]

113. Velikova, M.; Bankova, V.; Marcucci, M.C.; Tsvetkova, I.; Kujumgiev, A. Chemical composition and biological activity of propolis from Brazilian meliponinae. Z. Naturforsch. C J. Biosci. 2000, 55, 785-789. [CrossRef]

114. Velikova, M.; Bankova, V.; Tsvetkova, I.; Kujumgiev, A.; Marcucci, M.C. Antibacterial ent-kaurene from Brazilian propolis of native stingless bees. Fitoterapia 2000, 71, 693-696. [CrossRef]

115. Matsuno, T.; Matsumoto, Y.; Saito, M.; Morikawa, J. Isolation and characterization of cytotoxic diterpenoid isomers from propolis. Z. Naturforsch. C Biosci. 1997, 52, 702-704.

116. Matsuno, T. A new clerodane diterpenoid isolated from propolis. Z. Naturforsch. C Biosci. 1995, 50, 93-97.

117. Yoshida, M.; Saito, Y.; Matsuno, T. Diterpenoid from propoles as antitumor agent. EP532156A1, 1993.

118. Bankova, V.; Marcucci, M.C.; Simova, S.; Nikolova, N.; Kujumigiev, A. Antibacterial diterpenic acids from Brazilian propolis. Z. Naturforsch. C Biosci. 1996, 51, 227-280.

119. Matsuno, T.; Shioda, M.; Kano, K. Tumoricidal Activity of a New Clerodane Diterpenoid Isolated from Propolis; Monduzzi Editore: Milano, Italy, 1994; pp. 691-694.

120. Li, H.; Kapur, A.; Yang, J.X.; Srivastava, S.; McLeod, D.G.; Paredes-Guzman, J.F.; Daugsch, A.; Park, Y.K.; Rhim, J.S. Antiproliferation of human prostate cancer cells by ethanolic extracts of Brazilian propolis and its botanical origin. Int. J. Oncol. 2007, 31, 601-606. [CrossRef] 
121. Smith, E.C.; Kaatz, G.W.; Seo, S.M.; Wareham, N.; Williamson, E.M.; Gibbons, S. The phenolic diterpene totarol inhibits multidrug efflux pump activity in Staphylococcus aureus. Antimicrob. Agents Chemother. 2007, 51, 4480-4483. [CrossRef]

122. Haraguchi, H.; Oike, S.; Muroi, H.; Kubo, I. Mode of antibacterial action of totarol, a diterpene from Podocarpus nagi. Planta Med. 1996, 62, 122-125. [CrossRef]

123. Shapiro, S.; Guggenheim, B. Inhibition of oral bacteria by phenolic compounds. Part 1. QSAR analysis using molecular connectivity. Quant. Struct.-Act. Relat. 1998, 17, 327-337. [CrossRef]

124. Kubo, I.; Muroi, H.; Himejima, M. Antibacterial activity of totarol and its potentiation. J. Nat. Prod. 1992, 55, 1436-1440. [CrossRef]

125. Muroi, H.; Kubo, I. Antibacterial activity of anacardic acid and totarol, alone and in combination with methicillin, against methicillin-resistant Staphylococcus aureus. J. Appl. Bacteriol. 1996, 80, 387-394. [CrossRef]

126. Nicolson, K.; Evans, G.; O'Toole, P.W. Potentiation of methicillin activity against methicillin-resistant Staphylococcus aureus by diterpenes. FEMS Microbiol. Lett. 1999, 179, 233-239. [CrossRef]

127. Gibbons, S. Plants as a source of bacterial resistance modulators and anti-infective agents. Phytochem. Rev. 2005, 4, 63-78. [CrossRef]

128. Evans, G.B.; Furneaux, R.H.; Gainsford, G.J.; Murphy, M.P. The synthesis and antibacterial activity of totarol derivatives. Part 3: Modification of ring-B. Bioorg. Med. Chem. 2000, 8, 1663-1675. [CrossRef]

129. Micol, V.; Mateo, C.R.; Shapiro, S.; Aranda, F.J.; Villalain, J. Effects of (+)-totarol, a diterpenoid antibacterial agent, on phospholipid model membranes. Biochim. Biophys. Acta 2001, 1511, 281-290. [CrossRef]

130. Bernabeu, A.; Shapiro, S.; Villalain, J. A MAS-NMR study of the location of (+)-totarol, a diterpenoid bioactive molecule, in phospholipid model membranes. Chem. Phys. Lipids 2002, 119, 33-39. [CrossRef]

131. Mateo, C.R.; Prieto, M.; Micol, V.; Shapiro, S.; Villalain, J. A fluorescence study of the interaction and location of (+)-totarol, a diterpenoid bioactive molecule, in model membranes. Biochim. Biophys. Acta 2000, 1509, 167-175. [CrossRef]

132. Osawa, M.; Anderson, D.E.; Erickson, H.P. Reconstitution of contractile FtsZ rings in liposomes. Science 2008, 320, 792-794. [CrossRef]

133. Jaiswal, R.; Beuria, T.K.; Mohan, R.; Mahajan, S.K.; Panda, D. Totarol inhibits bacterial cytokinesis by perturbing the assembly dynamics of FtsZ. Biochemistry 2007, 46, 4211-4220. [CrossRef]

134. Evans, G.B.; Furneaux, R.H.; Gravestock, M.B.; Lynch, G.P.; Scott, G.K. The synthesis and antibacterial activity of totarol derivatives. Part 1: Modifications of ring-C and pro-drugs. Bioorg. Med. Chem. 1999, 7, 1953-1964. [CrossRef]

135. Evans, G.B.; Furneaux, R.H. The synthesis and antibacterial activity of totarol derivatives. Part 2: Modifications at C-12 and O-13. Bioorg. Med. Chem. 2000, 8, 1653-1662. [CrossRef]

136. Salazar, F.J.; Quintero, A.; de Domínguez, N.G.; Concepción, J.L.; Acosta, M.E.; Tropper, E.; Villamizar, J.E. Synthesis, antimalarial and antileishmanial activity of novel 13-benzyl-15,16-bisnorlabdane derivatives. J. Chem. Res. 2013, 37, 657-661. [CrossRef]

137. Simpson, B.S.; Claudie, D.J.; Gerber, J.P.; Pyke, S.M.; Wang, J.P.; McKinnon, R.A.; Semple, S.J. In vivo activity of benzoyl ester clerodane diterpenoid derivatives from dodonaea polyandra. J. Nat. Prod. 2011, 650-657. [CrossRef]

(C) 2017 by the authors. Licensee MDPI, Basel, Switzerland. This article is an open access article distributed under the terms and conditions of the Creative Commons Attribution (CC BY) license (http://creativecommons.org/licenses/by/4.0/). 